\title{
Abjection in Dambudzo Marechera's The House of Hunger
}

\section{Christopher Wayne \& Bridget Grogan}

Christopher Wayne is a master's candidate at the University of Johannesburg and a Global Excellence Scholarship recipient. His research area is marginal identities and abjection.

Email: christopher.wayne@hotmail.com

Bridget Grogan is a senior lecturer and NRF rated researcher in the Department of English at the University of Johannesburg. She is currently researching corporeality and metaphors of the body in Southern African writing. Email: bmgrogan@uj.ac.za

DOI: dx.doi.org/10.17159/2309-9070/tvl.v.55i2.1884

\section{Abjection in Dambudzo Marechera's The House of Hunger}

In a description of nationalist poems about "a golden age of black heroes; of myths and legends and sprites" (Marechera 74), the narrator of The House of Hunger (1978) observes that these themes are the "exposed veins dripping through the body of the poems." In this article we extend this observation to argue that, metaphorically on display in Marechera's novella itself, are the "exposed veins dripping through the body of the [text]" (74). The novella's themes include colonialism, social destitution, violence, state-sanctioned oppression, identity struggles, poverty, dislocation, disillusionment and anger, all of which are appropriately imaged in Marechera's visceral metaphor of the pain and violence implicit in the literary text. More specifically, corporeal imagery emphasises the unnamed narrator's troubled existence, suffusing The House of Hunger in a manner that elicits disgust and horror, thus encouraging the reader's affective response to the representation of the colonial condition. This article illuminates Marechera's seeming obsession with corporeality by providing a postcolonial and psychoanalytic reading, focussing in particular on Julia Kristeva's theory of abjection. Although critics have objected to reading African texts through the lens of psychoanalysis, the article sets out to address this concern, noting the importance of theorists like Frantz Fanon and Joshua D. Esty in justifying psychoanalytic readings of African literature, and drawing resonant parallels between Kristevan theory and Marechera's perspective on the colonial condition of Zimbabwe (Rhodesia) in the 1970s. Keywords: abjection, African literature, corporeality, postcolonialism, psychoanalysis.

\section{Introduction}

In the 1999 preface to Emerging Perspectives on Dambudzo Marechera, Dennis Brutus notes that Marechera, "as he often insisted", was "exposed to a wide range of literatures and ideas from many cultures and this gave his writing a freedom and a wide range of imagery that many found unfamiliar and even shocking" (Brutus ix). Perhaps because of his exposure to multinational, multicultural literature and his consequent literary range, Veit-Wild and Chennells (xi) observe that Marechera has "often been regarded as the "man who betrayed Africa'"; that he "broke ranks with the sort of nationalism which gave a peculiar authority to pre-colonial African culture" and his "art refused to be rooted in an Africa which the political and cultural officialdom of the 1960s and 1970s imagined". Marechera's prodigious reading enabled him to "place Africa in a broader context than that provided by either indigenous cultures or by a simple opposition of European imperialism and African resistance" (Veit-Wild and 
Chennells xi). Moreover, he "refused to claim peculiar merits for blackness" because he "hated racism and therefore rejected racial taxonomies" (Veit-Wild and Chennells ix) as a means to combat it. For Veit-Wild and Chennells (xi), the "enormous importance of Marechera is that while his compatriots were still fighting for national liberation, his endeavour was to dismantle the 'African image'" and he "recognized that 'culture' was being invoked to authorize and thus disguise the tyrannies of many of the regimes which came to power in the 1960s and 1970s".

In a discussion of postcolonial criticism and theory, Hans Bertens (194) argues that the "desire for cultural self-determination, that is for cultural independence, is one of the moving forces behind the literatures that in the 1960s and 1970s spring up in the former colonies". Yet Marechera's writing seems to indicate that cultural independence is not so easily achieved — that it might even be impossible—owing to the multicultural influences exerted on the former colonies largely as a consequence of colonisation. Intertextuality and global cultural references permeate The House of Hunger accordingly.

Indeed, Marechera refused to be categorised as an "African writer"—he objected to the notion that "any writer should be bound to further the interests of nation or race" (Veit-Wild and Chennells xii). Thus, for Helon Habila, Marechera is nothing like any African writer before him:

Up until the time he appeared, the leading writers like Chinua Achebe, Ngũgĩ wa Thiong'o and Ayi Kwei Armah had written in an accessible, social realist mode, and most of the writers that came immediately after them adopted the same style, not only because of the earlier writers' influence, but also because of the effectiveness of this very accessible style in presenting the anti-colonial, nationalist themes that had become the predominant concern of early post-colonial African fiction. (Habila 256-7)

Discussing Marechera's refusal of nationalism, social realism and an anti-colonialism that simply reverses colonial binaries, Veit-Wild and Chennells (xiii) argue that the fundamental achievement of postcolonialism has in fact been "to show that as long as the colonial encounter is imagined in binarisms of coloniser and colonised, oppression and resistance, foreign and native, neither has an identity outside a paradigm of mutual dependence". A system of binarisms, like colonialism, employs oppositions "in the cultural construction of reality" (Ashcroft et al. 23). Consequently, much postcolonial theory is premised upon colonialism's construction of the "other". Famously, for example, Edward Said's Orientalism focuses on the way in which Western discourse seeks to "control, manipulate, even to incorporate" the Oriental "other" (Said 13); and Abdul JanMohamed, in Manichean Aesthetics and elsewhere, states clearly that the "dominant model of power-and-interest-relations in all colonial societies is the Manichean opposition between the putative superiority of the European and the supposed inferiority of the native" ("Economy" 63). The binary colonial system of "self" and "other" suppresses "ambiguous or interstitial spaces between the opposed categories, so that 
any overlapping region [...] becomes impossible according to binary logic, and a region of taboo in social experience" (Ashcroft et al. 23-24). Postcolonial theory thus operates to recuperate the "region of 'taboo' - the domain of overlap between these imperial binary oppositions, the area in which ambivalence, hybridity and complexity continually disrupt the certainties of imperial logic" (Ashcroft et al. 25-26). Homi Bhabha's notion of the "Third Space", for example-the interstitial, liminal space between colonising and colonised cultures, "where the negotiation of incommensurable difference creates a tension peculiar to borderline existences" (The Location of Culture 312) - is one way in which the political tension of a "region of taboo" is theorised.

Yet tropes in literature also reveal taboo and liminality. In his seminal article, "Excremental Postcolonialism", Joshua D. Esty notes the function of scatology as a governing trope in postcolonial African writing. Observing that psychoanalysis posits "shit [as] the first instancing of the other" (Esty 34) that is nonetheless deeply imbricated with the self, he reveals how the trope is particularly salient in African writing, and especially relevant to depicting the region of taboo created in the cultural contact zone where the notions of "self" and "other" occur so prominently: "If, in the colonial era, shit often functioned as a sign of the actively denigrated native it also comes to function, in the decolonisation era, as a sign of the actively repudiated ex-coloniser, the alien and unwanted residue of a sometimes violent political expulsion" (Esty 30). Indeed, just before the advent of Zimbabwean independence, Marechera foregrounds the region of taboo in social experience. The House of Hunger is permeated with imagery of corporeality — the abject (Kristeva's category of taboo and interstitiality) - in order to disrupt the certainties of imperialism as well as the logic of a cohesive sense of self, impossible under colonial conditions. This imagery reveals the uncertain, shifting dynamics between the notions of "self" and "other" that both support and undermine each other. In reading the novella against Kristeva's theory of abjection, the uncoupling of colonial and subjective (inside/outside) binaries will become apparent. This uncoupling is important: as Ashcroft et al. point out, the "danger for anti-colonial resistance comes when the binary opposition is simply reversed, so that 'black', for instance, or 'the colonized', become the dominant terms. This simply locks the project of resistance into the semiotic opposition set up by the imperial discourse" (Ashcroft et al. 26). Marechera, in exposing abject corporeality, and in applying the trope to both coloniser and colonised, refuses the reversal of binary oppositions and remains focused on the liminal region of taboo.

Indeed, The House of Hunger is saturated with abject images that do not reverse binaries but instead appear to dismantle them. As Kristeva shows, abjection dismantles the binarism of self/other, resulting in a loss of subjectivity that threatens the cultural construction of reality. Jane Bryce argues that in The House of Hunger the body is "smashed, dismembered, distorted, so that the imagination can attain heights of insight, revealed in the material form of writing itself" (Bryce 232). Especially in its use 
of language and imagery, Marechera's text itself seems corporeal, a site of abjection in the material form of writing. This article explores this "body" of text.

Importantly, corporeality in Marechera is inextricably linked to the colonial context. Taitz (232) notes of The House of Hunger that the "fracturing violence of colonialism is exposed [...] through violent events that leave behind scars and stains, that crush, dismember, and fracture". The House of Hunger exposes these scars and stains in its evocation of the abject, which also functions to question the stability of identity. Identity in the novella, as Taitz (24) observes, is "in essence unstable, ever-changing, and in need of constant redefinition". Abject imagery promotes this instability, emphasising identity as constantly challenged and under erasure. The narrator is in search of a sense of self, and "the family, the community, the nation, and the state" each ascribes to him a "particular definition" of who he is; however, "as he explores each different arena, he experiences a sense of disillusionment with their inadequacy to represent him" (Taitz 25). The narrator's anonymity-he remains unnamed throughout the text-emphasizes the loss of individuality and subjectivity that may be ascribed to nationalism and state oppression.

Taitz (36) argues that colonial intervention imposes a "new frame of reference" on the colonised subject, but that this frame of reference is constantly "undermined by the traces of an earlier frame of reference-subjectivity". This means that the subjectivity of the colonial subject contradicts colonial influence, leading to a "splitting of the self, a fragmentation, where 'othering' is concretised in a double consciousness and double-voicedness and in a condition of alienation" (Taitz 23). Through abjection, Marechera voices this conflict and expresses the fragmentation of subjectivity and the threat under which it constantly exists. As Esty (54) observes, stable identity is impossible under oppressive colonialism or nationalism and this uncertainty influences the literary text: "where the artist flies from the squalid constraints of history yet is impelled back to the question of nation, it is not surprising to find texts that are profoundly self-divided"; these texts are often suffused with "scatological selfdoubt", themselves becoming "excrement, excess, superfluity".

Taitz (36) notes, moreover, how relationships in the novella are "fractured", including the relations between the coloniser and the colonised. The House of Hunger attempts to disrupt a "colonial narrative which seeks to impose a unified, monolithic, and homogenous identity upon the subjects of colonization" (Taitz 36). However, the novella not only endeavours to undermine this narrative of the coloniser, it also seeks to dismantle the "African image" of postcoloniality. As Veit-Wild and Chennels (ix) emphasize, Marechera's writing "refused to be rooted in an Africa which the political and cultural officialdom of the 1960s and 1970s imagined".

\section{A psychoanalytic reading of postcolonial texts}

Many critics have argued against reading postcolonial texts through the lens of 
psychoanalysis. They maintain that doing so imposes on these texts a Western form of reading aligned to nineteenth-century colonialism. Consequently, taking a psychoanalytic approach to a postcolonial text is deemed counter-productive to the postcolonial agenda "to disestablish Eurocentric norms of literary and artistic values" (Abrams and Harpham 307). Yet inherent in Marechera's writing is a strong tension between postcolonialism and European influence, thus problematising an exclusively postcolonial focus on his writing, and opening up the potential for a psychoanalytic approach to his work.

Brendon Nicholls addresses the difficulties inherent in the psychoanalytic approach to reading postcolonial texts. He outlines some of the aforementioned critiques of psychoanalysis:

There are considerable theoretical pitfalls in invoking a psychoanalytic framework in relation to postcolonial writing and subjectivity. Indeed, postcolonial theory has extensively critiqued the founding assumptions and the institutional complicities of psychoanalysis. In fact, it is possible to problematise psychoanalysis on historical, conceptual, diagnostic, institutional, and experiential grounds. (Nicholls 2)

Additionally, Nicholls (2) maintains that, "[d]iagnostically, a psychoanalytic approach to African literature risks instituting a universal explanatory category that elides political specificities". He observes that "psychoanalysis's key assumptions and practices - its embedded standards of normality and deviance, and the therapeutic rehabilitation of agitated states through self-disclosing utterances-cannot be completely separated from the utterly abnormal and aberrant effects of colonial surveillance, torture, and suppression" and that psychoanalysis is "inseparable from world-historical ambitions of nineteenth-century European imperialism" (Nicholls 3). He argues correctly that psychoanalytic readings of African literature therefore "need to acknowledge the interior lives of African subjects while avoiding the conceptual minefield of psychoanalysis in its normative or regulative dimension, as well as the political complicities of colonial psychiatry and ethnopsychiatry" (Nicholls 3).

Yet as Frantz Fanon's writing, combining psychoanalysis and political critique, reveals, psychoanalysis is not inimical to understanding the colonised subject's experience. As Fanon observes, "[t]he defensive positions born of [the] violent confrontation between the colonized and the colonial constitute a structure which [...] reveals the colonized personality" (Fanon 182). Homi Bhabha observes, moreover, that "[i]t is Fanon's great contribution to our understanding of ethical judgment and political experience to insistently frame his reflections on violence, decolonization, national consciousness, and humanism in terms of the psycho-affective realm" ("Foreword" xix). This psycho-affectivity, he observes, may appear to imply a problematic cultural universality (or the "normative or regulative dimension" of psychoanalysis that Nicholls views as a by-product of European imperialism). However, Bhabha notes 
its contextual dimension, and thus its social, political, and historical specificity: "it is only ever mobilized into social meaning and historical effect through an embodied and embedded action, an engagement with (or resistance to) a given reality, or a performance of agency in the present tense" ("Foreword" xix). Attention to the body and corporeality is thus fundamentally important to an analysis of postcolonial psycho-affectivity.

A psychoanalytic approach to Marechera is thus relevant for two reasons. First, Marechera's writing does not subscribe to an African ideology that separates itself from historical European influences by striving to return to a pre-colonial culture or a culture independent of colonial influence. Instead, it acknowledges that European influences cannot be dismissed. The psychoanalytic reading of Marechera's novella that we employ in this essay does not attempt to apply "standards of normality and deviance", nor does it seek to apply to the novella a "normative or regulative dimension", which is a constituent part of nineteenth-century psychoanalysis during the period of European imperialism. Nicholls (4) suggests that "when we encounter psychopathologies or perversities at work in African literary texts, we should at least consider the possibility that these features contain a political logic that emerges from the history of colonization or that these features amount to a tactical logic for working with colonialism's contemporary legacies". Fanon's approach to colonised subjectivity invokes this political logic, opening up our second justification for a psychoanalytic reading: Marechera, like Fanon, does not shy away from the possibility that an African text or the representation of African/colonised experience may contain "psychoanalytic" features relating to colonialism.

Julia Kristeva's Powers of Horror: An Essay on Abjection elucidates the concepts of the "abject" and "abjection". The abject refers to aspects of the self that traverse the borders of the body, forming a part of it, but also existing outside of it as waste; for example, loathed foods, bodily products and, most emphatically, the corpse. The subject recoils in horror from the abject, which threatens its sense of itself as a discreet, "clean and proper" entity (Powers of Horror 8). Although the abject cannot be considered as such, it is a part of the self that must be perpetually rejected and othered in order for subjectivity to be bolstered. As Noëlle McAfee explains, abjection creates the "borders of an always tenuous ' $\mathrm{I}^{\prime \prime}$ " (McAfee 45); it is the "process that initiates and maintains the construction of subjectivity" (Grogan, "Abjection and Compassion: Affective Corporeality in Patrick White's Fiction" 95). It begins as a "phase of development in which the child acquires language and begins to take its place as a speaking subject within the symbolic order" (Grogan "Abjection" 95). An affective state "equivalent to horror", occurring in conjunction with the acquisition of language (which itself severs the child from the world through the substitution of representation), it protects the self from "those things [...] relegated to the periphery or beyond the boundaries of civilized humanity" (Bryce 227). Marechera's abject 
text thus threatens "orderly", "acceptable", and "social" identities—-the "orderly" identities colonialism violently attempted to construct.

Encountering the abject, so carefully distanced from the notion of the "self" via psychoanalytic repudiation, thus equates to a "loss of meaning, a breakdown of the distinction between the subject and the object, a collapse of the symbolic order" (Mansfield qtd. in Rudge and Holmes 4). Additionally, "the abject challenges established 'systems of order, meaning, truth [...] and laws that produce a controlled and manageable subject'" (Rudge and Holmes 4). The question arises whether the abject is "still part of me because it comes from me? Do I own it? Because of this uncertainty, the lines that differentiate the inside from the outside of the body shift and fluctuate, thus destabilizing the sense of subjectivity" (Rudge and Holmes 4). In this essay, we argue that The House of Hunger is saturated with images of abjection. While Bryce (227) maintains that Marechera's imagery of stains "bears witness to his conscious transgression of the boundaries" of what is social and therefore acceptable, we further postulate that Marechera represents the human body (the abject in particular), and the violence to which it is often subjected, in a way that reveals the destabilisation of subjectivity within the political and national climate of 1970s Zimbabwe (Rhodesia).

\section{Abjection in The House of Hunger}

The plot of The House of Hunger is not easy to establish or articulate because it is a novella of fragmentation: the timeframe is achronological, shifting between the narrator's memories and events in the present. Additionally, the identities of various characters are not immediately known nor elaborated upon. Habila, however, summarises the novella as follows:

The House of Hunger is set in 1970s Zimbabwe (then Rhodesia), in the repressive years of Unilateral Declaration of Independence (UDI) of the white minority government of Ian Smith. These were also the years of the war of independence. The story opens with the nameless narrator leaving "The House of Hunger"; on the way he stops at a bar where he runs into friends-first Harry, then Julia—-the bar then becomes the immediate, concrete setting of the story, and from then on the narrative progresses in seemingly unconnected flashbacks and lengthy digressions. (Habila 257)

Bryan Mukandi, in a 2009 opinion piece for Mail and Guardian focusing on the African economic climate, refers to the novella's continuing relevance. He observes that it "spells out [Marechera's] suspicions of the liberation movement, its leaders, and the prospects for the future" (Mukandi). He argues, moreover, that it is an "impolite, almost crass work, [and] is a slap in the face that demands the reader ask difficult questions about the state of the world". He notes that although it is "a difficult book to make sense of [...] a theme that emerges from its loosely connected series of stories is both frustration with the inequalities that were present at the time, as well 
as a scepticism of the future". Pertaining to the novella's status as autobiographical, Bryce (226) comments that "[w]e know from biographical evidence contained in the Source Book that the description of childhood in 'House of Hunger' is drawn from the events of Marechera's own early life". Critics therefore suggest that The House of Hunger presents Marechera's personal struggle with his own subjectivity or identity growing up as a disillusioned youth in Rhodesia, a country vying for independence amid state-sanctioned oppression and violence.

Chris Power observes that "the majority of [Marechera's] works are written in a sometimes difficult stream-of-consciousness style" and his writing presents "deliberately confused timelines, disorienting shifts between external event and internal process, and the predilection for the grotesque" (Power). Marechera writes "in English, his second language (his first was Shona)" and his "prose exudes tension. He considered English a form of combat, a process of 'discarding grammar, throwing syntax out, subverting images from within, beating the drum and cymbals of rhythm, developing torture chambers of irony, sarcasm, gas ovens of limitless black resonance'" . Power's description suggests the abject nature of Marechera's style itself, its predilection for what Kristeva has referred to as the "semiotic" dimension of language.

Marechera's characters are, moreover, "typically outsiders" (Power), much like Marechera himself, according to several African critics. Habila (257) notes that Marechera's main critics were "fellow Africans who saw his dalliance with European modernism as a betrayal of the anti-colonial struggle"; in a sense, one might argue that Marechera's interest in Europe, in modernism, ejected him from a community of African writers, rendering him abject, one might say. For Okonkwo, for example, his "excessive interest in sex activity, his tireless attempt to rake up filth, [was] alien to Africa-a continent of hope and realisable dreams" (qtd. in Power). Additionally, Okonkwo maintained that Marechera had "grafted a decadent avant-garde European attitude [...] and style to experiences that emanate from Africa", a style of "distorted and self-destructive sophistication" that, according to her, Africa could ill afford (qtd. in Habila 257). Certainly, Marechera did not write to satisfy nationalist attitudes nor cultural assumptions of the African continent. Annie Gagiano therefore argues that the "discomfiture of some critics with the African cosmopolitanism or African modernism embodied in Marechera's work" relates to a representative passage in Ngũgĩ wa Thiong'o's influential 1986 essay collection, Decolonising the Mind, which declares that if an African acquires the "thought-processes and values of the foreign tongue" he or she becomes distanced or "alienated from the values of his mother-tongue or from the language of the masses" (Habila 257). Marechera, however, commented on the subject of African nationalism, "in his typical eloquent and iconoclastic manner [...]: 'If you are a writer for a specific nation or a specific race, then fuck you'"' (Habila 257). 
The metaphoric "House of Hunger", as Bryce (231) suggests, is "both a place and a habitation, and the body and the mind". The novella's title, through the reference to hunger, invokes the tension between the inside and the outside of the body that constitutes a significant aspect of the text and that harnesses the imagery of abjection. In The House of Hunger, not only is literal food desperately required, owing to the narrator's poverty, but also the social, political, and cultural nourishment lacking in the lives of the voiceless and powerless in Rhodesian society. Here both the literal body and the social body are starving; Marechera's writing renders both "bodies" abject in order to suggest the corrosion not only of individual subjectivity but also of systems of oppression. In this way, he subscribes to the way in which, according to Esty (44), African writers suspicious of colonialism and nationalism use corporeal or "excremental tropes to register the tension between the demands of the [...] subject and the demands of the social collective".

Thus, according to Bryce (223), "[s]exuality and the body are, for Marechera, a template for social reality, so that his narrative of post-Independence Zimbabwe is in a very real sense "written on the body'". Moreover, she observes the "slipperiness" of boundaries in Marechera's imagery as well as the "elision of discrete categories, the replacement of sharply defined difference by multifarious diversity, the metonymic correspondence of body/nation, the ease of transition between inner and outer, and the embodiment of all this in language itself" (Bryce 222). Of interest here is Marechera's "ease of transition between inner and outer" and the "slipperiness" between boundaries that the novella emphasizes, precisely the effects of abjection.

The opening pages of The House of Hunger, emphasising the link between the social body and the individual body, foreground Rhodesia's police brutality and government oppression. The narrator's father, for example, "once got into trouble for begging and loitering. And then Peter got jailed for accepting a bribe from a police spy" (12). A strong theme of political oppression is thus established, especially in relation to education and ideas, an oppression from which the narrator does not escape. At the beginning of the novella he is "arrested like everybody else for a few hours" when he and others "rushed out into the streets to protest the discriminatory wage-structure" (12). He and "[a]ll the black youth [were] thirsty for selfknowledge" and he believed that he "could find it in 'political consciousness"" (12). He mentions that there "was not an oasis of thought which [they] did not lick dry; apart from those which had been banned, whose drinking led to arrest and suchlike flea-scratchings" (12). Metaphors of consumption are therefore employed, relating to the novella's title and depicting the narrator and his fellow students' attempts to quench their thirst for knowledge and sustain dissent within an oppressive society. However, the knowledge that they consume, regulated by colonial power, results in "flea-scratchings" — signifiers of another form of consumption, a parasitism turned 
against them-alerting the reader to the abject corporeal imagery Marechera uses to describe the oppression and control of the police.

Imagery of oppression, linked to imagery of ingestion and thus to the prevailing trope of the "House of Hunger", continues throughout the novella with mention of "arrests en masse at the university"; "when workers came out to strike there were more arrests" (13). These arrests were "so much a part of one's food that no one even turned a hair when two guerrillas were executed one morning and their bodies later displayed to a group of schoolchildren" (13, emphasis added). According to Kristeva, "food, an absolute necessity for keeping the body alive, inevitably breaks down into digested waste material and in this way mirrors the reality that the body will eventually die and decompose" (Rudge and Holmes 3). Kristeva maintains that "a corpse constitutes the utmost portrayal of the abject" when "a living body" is in "proximity of a cadaver" (Rudge and Holmes 3). Marechera describes arrests as toxic "food" and the Rhodesian government exposes children to the horror of corpses, threatening and dismantling their incipient, innocent subjectivities. Thus the colonial government removes all agency from its colonised subjects, oppressing them further and maintaining a culture of subjugation premised on a loss of individuality.

While oppression is figured as food in the descriptions above, shoved down the gullets of the oppressed, resistance of a kind is figured in abject acts of expulsion. In a description of a conversation, "Peter, as usual when something indistinct disgusts him, farted long and loudly and spat in [the narrator's] general direction, and muttered something about capitalists and imperialists" (20). The close link here between "capitalists and imperialists" and the abject intrusion into "proper" life challenges these ideologies. Like Marechera, Peter invokes the abject to threaten such authority. The abject is thus brought to the fore by political, economic, social, and police oppression: what is eaten must be expelled. This abjection occurs in two related ways, as Marechera's writing suggests. In the racist Rhodesia of Marechera's novella, white people "abject" those they consider "other" to themselves: black people. The white government, for example, tries to "expel" black people, by cordoning them off with "Whites Only" signs (37). By doing so, they construct their sense of a "superior" identity. However, what they abject (blackness) threatens this subjectivity-in Marechera's imaginary, black characters like Peter rebel by deliberately invoking the abject and by engaging in behaviour that foregrounds the bodily limit between the inside and the outside.

The interconnection Marechera postulates between white and black forms of abjection is evident in a striking image. The narrator observes: "Something fighting floated down from a pale blue sky. As it floated down to my level I saw it was a black man and a white man locked in the embrace of struggle" (52). This description seemingly provides an image for Homi Bhaba's argument that "the encounter of colonizer and colonized always affects both" (Bertens 207); they are "locked in the embrace 
of struggle". The colonization of Rhodesia is presented here as a process that has affected-and continues to affect-both the colonized and colonizer. When either party tries to reject (abject) the other, they inevitably reject (abject) themselves; in other words, their own identity is premised upon the identity of the other and the identity of the "other" is set up in threatening opposition to the "self" s' provisional subjectivity.

However, in relation to the oppressed, abjection, while it may figure as imagery of resistance, is often also turned against the self. Marechera's explicit narrative treatment of the body and its functions reveals his anti-nationalist attitudes, but when the narrator declares in the first line of the novella, "I got my things and left", he reviews "all the details of the foul turd which my life had been and was even at that moment" (11). Here, at the very outset of the text, abjection is not only evident in the imagery but also reflected in the fragmentary narration-the Kristevan semiotic-and the uncertainty of subjectivity that the opening sentence suggests (Who is this character? Why is he leaving? From where?). The narrator observes:

In the House of Hunger diseases were the strange irruptions of a disturbed universe. Measles or mumps were the symptoms of a malign order. Even a common cold could become a casus belli between neighbours. And add to that the stench of our decaying family life with its perpetual headaches of gut-rot and soul-sickness and rats gnawing the cheese and me worrying it the next morning like a child gently scratching a pleasurable sore on its index finger. (18)

Here the breakdown of the boundaries between the "horrific" and the "clean" is strongly emphasised. The narrator's society is defined by the collective social, cultural and political disease, the "malign order" of the social body. This malign order is shared by the oppressor and oppressed, but is most significantly lived by the latter. Thus the narrator's internal monologue reveals his beaten morale: "My generation had all but been consumed by gut-rot" (59). Social aberrations-such as violence-are exposed and have consumed the narrator's generation, resulting in social decay and loathing, both other- and self-related. Marechera thus "worries" the theme of social decay, like, as he puts it, "a child gently scratching a pleasurable sore on its index finger" (18).

Unsurprisingly, then, abject imagery accumulates in The House of Hunger, indexing social and individual degradation, a narrative fascination with corporeality expressed through the character, Julia, who contemplates the human body: "Tubes [...] That's what being human means. Insides. Entrails. All twisted up in a knot. A red knot"; to which the narrator replies, "The augury of life-steaming entrails" (61). Julia says, "When I was young [...] I wanted to look at my insides. Rip them inside out and see what I really was like" (61). Like Julia, Marechera insists on exposing the viscera, on looking at them and revealing them in the attempt to destabilize identity. 
Indeed, the corporeal abject disrupts the seemingly congruent border between the subject and society and Marechera's interest in abjection draws together the oppressor and the oppressed, defying the boundary between them. Certainly, the trope of the abject within the novella distorts the boundary between subject and object: as argued above, images of the abject "connect" the characters into a single, social body because the boundaries between them become obscure as they are subjected to the same system of subjugation. Alan Ramón Ward, without taking a psychoanalytic approach, phrases this differently: "Individualism is rejected in the space Marechera calls the House of Hunger in favour of a collective vision in which each person is alienated from the direct experiences of his or her body" (73). As Grogan notes, "[g]roup identity, like individual subjectivity, is maintained via abjection" (" $(\mathrm{Im})$ Purity, Danger and the Body in Doris Lessing's The Grass is Singing" 32). Through the image of the stain, Marechera too suggests the interconnection between society (or political cohesion) and the oppressed individual. The narrator, for example, recounting his father's death, links it to the machinery of twentieth-century colonialism: "The old man died beneath the wheels of the twentieth century. There was nothing left but stains, bloodstains and fragments of flesh, when the whole length of it was through with eating him" (60). The narrator believes that "the same thing is happening to [his] generation" (60). The "stain" is a motif throughout the novella that represents the loss of individuality and social liberties. The "bulldozers have been and gone and where once our heroes danced there is nothing but a hideous stain" (60).

White characters, Marechera suggests, are also not immune to the reducing logic of the stain. Richter, a white student whom the narrator meets "by chance" and whom the military had left with "locust-like raspings of wings in his mind" (86) when they were done with him, goes about "meticulously dissect[ing] silence", a characteristic the narrator admires, by "scalpelling it to its very entrails and with a sterile pin pointing out to us organs of interest". In other words, he provides "invariably harrowing accounts of atrocities he had either witnessed or taken part in" (86). When Richter dies, he too is "crunched to a stain by a train" (86), invoking again the metaphor of "the wheels of the twentieth century". Thus Richter, despite being white, is also deprived of individuality under the domination of the state. Yet Marechera not only criticizes the dominating white government, he also criticizes his fellow black citizens. He notices: "The barman, impressed by [Julia's] massive breasts, was thoughtfully reducing her to a stain on a sheet. A true hero of our time. Reducing everything to shit" (55). Again, the motif of the "stain" is reiterated to indicate the loss of individuality and the corruption of social life extending into the distorted lives and behaviour of each individual.

Marechera thus compares the "impropriety" of bodily functions to abject human society, which, much like the repressed aspects of the human body, is viewed as "unclean" and "improper". The narrator condemns human endeavours throughout 
history: "we are all sticky with the stinking stains of history" (57). This is perhaps why Marechera does not subscribe to a nationalist ideology or one of heroic resistance, either of which would attempt to establish a circumscribed culture based upon the abjection of difference: for him, few groups of people have been isolated from "outside" influences; in other words, few groups have been left "unstained" by history.

Further illustrating this point, the narrator describes his best friend Phillip's poems. He observes in them "songs of a golden age of black heroes; of myths and legends and sprites. And ghouls. These were the exposed veins dripping through the body of the poems. One of them was about Julia and [him]self; it was entitled 'Something Rotten'" (74). The poem reminds the narrator of an abject scenario: it was a "time when I was writing an article about shantytown and while inspecting the pit-latrines there I fell into the filthy hole. I am still not quite recovered from the experience" (74). The narrator still embodies this encounter with the abject, in all its horror and trauma: it is part of the colonial condition linked, moreover, to his suspicion of a heroism based upon racial and nationalist identity. Ambiguously, the "filthy hole" signifies the "pit-latrines" but could also connote the narrator's state of mind upon seeing the conditions in which people must live, or upon responding to various political ideologies-a state of mind that remains with him.

Kristeva's theory that "cultures have set up rituals" (Powers of Horror 49) to deal with the threat of abjection perhaps explains the use of abject imagery in literature. Within modernity, including within the twentieth-century colonial order, where "societies develop and religions wane, art takes over the function of purification, often by conjuring up the abject things it seeks to dispel" (Powers of Horror 49). Literature thus provides a "catharsis and purging of what is deemed other or abject", meaning that "often these literary products show a dark side of humanity" (Powers of Horror 57). Marechera's litany of abject imagery throughout The House of Hunger arguably attempts to cleanse the abjection of his own social reality. Habila (256), suggesting this cathartic dynamic, quotes David Kerr, arguing that it is "the possibility of art as a solution to the meaningless contingency of life that allows Marechera to create The House of Hunger at all, and he is acutely aware that the very act of writing the novella is almost an act of defiance, plucking meaning from chaos". While Marechera appears to write to express the collapse of meaning, it is also the act of writing that creates meaning for him. The House of Hunger is thus saturated with images of corporeality to the extent that the text itself appears corporeal and becomes abject, illustrating Kristeva's assertion that literature often exhibits a dark, abject side of humanity. Indeed, Bryce (257) argues that the "aspects of existence which social codes function to contain, repress and censor, are brought to light by the artist, who symbolically on our behalf confronts our deepest fears: fear of defilement and death"; in other words, the abject.

Marechera, however, also confronts the deepest fears of the colonial order. As Mansfield (4) argues, "the abject challenges established 'systems of order, meaning, 
truth and law $[\ldots]$ and laws that produce a controlled and manageable subject'". The white, colonial social body views blackness as "social excrement" and seeks to discharge it from the inside of the body politic to the outside. Grogan notes that the inherent problem in this process of othering and expelling is that "excrement" is an example of "a part of the body that can never be finally expelled" ("( $I m)$ Purity" $32)$; in the same way, the white social body cannot expel the "others" it constructs in the attempt to prop up its identity. Bryce (228), in her discussion of the imagery in another of Marechera's works-Black Sunlight_observes how the characters are "victims of torture rationalized by ideology" and are "society's excreta, that which it prefers to flush out of sight, but which the writer, through the medium of language, washes to the surface again". Colonial power in The House of Hunger requires the (black) body for its racist assumptions, which is perhaps why Marechera "tears the body apart" through the abject text, simultaneously rendering identity abject and thus inassimilable so that these kinds of meanings—-based on physical differenceswill become meaningless.

\section{Conclusion}

The House of Hunger (1978) predates Kristeva's theory of abjection, but Marechera shows how exposure to the abject creates horror and disgust and subsequently threatens oppressive subjectivities. Abjection emerges in the conditions created by a repressive government that seeks to police that which it considers abject, or "other", to itself. The House of Hunger is set in the context of the extreme violence and oppression of the ruling Rhodesian government. Its systems of power sought to repress black people, whom the colonial order considered abject- "unclean", "improper", and a threat to its sense of coherence, meaning, truth and law. Marechera's abject imagery emphasises this political dynamic but destabilises the boundaries between subject and object, "self" and "other". The House of Hunger, through abject imagery and textuality, indirectly reveals how the colonial regime enforced a loss of subjectivity on the colonised other and thus how it established a society on the basis of abjection. Yet Marechera's writing explicitly exposes the inside of the body to reveal how the abject constitutes everyone in his society. It is through the abject, then, that he reveals the threatened sense of self-of both the colonised and the coloniser-constituting subjectivity within a colonial context.

\section{Acknowledgement}

This work is based on research supported in part by the National Research Foundation of South Africa (Grant Number 109070). The opinions and conclusions expressed in the article belong to the authors alone, and the NRF accepts no liability in this regard. 


\section{Notes}

1. In Revolution in Poetic Language, Kristeva posits the terms "symbolic" and "semiotic" to refer respectively to the ordering signifying capacity of language and that characterised by the disordering, abject entrance of corporeality into language. John Lechte argues that the semiotic is evident in the "dynamic and unrepresentable poetic dimension of language-its rhymes, rhythms, intonations, alliterations - melody, the music of language" (Lechte 5); it is evident, moreover, in the disruption of grammar and syntax.

2. The relation between various characters in the novella is not always immediately clear; "Peter's" connection to the narrator is not established. Marechera therefore does not make it easy for the reader to establish the identities of the characters, which adds to the novella's emphasis upon the slipperiness of identity, the loss of subjectivity.

3. This quotation strongly recalls the first lines of Allen Ginsberg's "Howl", arguably drawing into the text another, among many, "western" influence similarly stimulated by the imagery of hunger, corporeality and abjection: "I saw the best minds of my generation destroyed by madness, starving hysterical naked, / dragging themselves through the negro streets at dawn looking for an angry fix" (Ginsberg 9, 11. 1-2).

\section{Works Cited}

Abrams, M. H. and Geoffrey Galt Harpham. A Glossary of Literary Terms. Wadworth, 2012.

Ashcroft, Bill, et al. Key Concepts in Post-Colonial Studies. Routledge, 1998.

Bertens, Hans. Literary Theory: The Basics. Routledge, 2001.

Bhabha, Homi K. "Foreword: Framing Fanon". The Wretched of the Earth. Frantz Fanon. Grove, 1994, pp. vii-xii.

. The Location of Culture. Routledge, 1994.

Brutus, Dennis. "Preface". Emerging Perspectives on Dambudzo Marechera. Eds. Flora Veit-Wild and Anthony Chennells. Africa World Press, 1999, pp. ix-x.

Bryce, Jane. "Inside/out: Body and Sexuality". Emerging Perspectives on Dambudzo Marechera. Eds. Flora Veit-Wild and Anthony Chennells. Africa World Press, 1999, pp. 221-34.

Esty, Joshua D. “Excremental Postcolonialism". Contemporary Literature vol. 40, no.1, 1999, pp. 22-59.

Fanon, Frantz. The Wretched of the Earth. Grove, 2004.

Ginsberg, Allen. Howl and Other Poems. City Lights Pocket Poets Series 4, City Lights, 2001.

Grogan, Bridget. "Abjection and Compassion: Affective Corporeality in Patrick White's Fiction". Journal of Literary Studies vol. 28, no. 3, 2012, pp. 93-115. DOI: https://doi.org/10.1080/02564718.2012.679509.

. "(Im)Purity, Danger and the Body in Doris Lessing's The Grass is Singing". English Studies in Africa vol. 54, no. 2, 2011, pp. 31-42. DOI: https://doi.org/10.1080/00138398.2011.626181.

Habila, Helon. "On Dambudzo Marechera: The Life and Times of an African Writer". Virginia Quarterly Review vol. 8, no. 1, 2006, 251-60.

JanMohamed, Abdul. Manichean Aesthetics: The Politics of Literature in Colonial Africa. U of Massachusetts P, 1983.

. "The Economy of Manichean Allegory: The Function of Racial Difference in Colonialist Literature". Critical Inquiry vol. 12, no. 1, 1985, pp. 59-87.

Kristeva, Julia. Powers of Horror: An Essay on Abjection. Columbia U P, 1982. . Revolution in Poetic Language. Columbia U P, 1984.

Lechte, John. Julia Kristeva. Routledge, 1990.

Marechera, Dambudzo. The House of Hunger. Heinemann, 2009.

McAfee, Noëlle. Julia Kristeva. Routledge, 2004.

Mukandi, Bryan. "The House of Hunger". Mail and Guardian, 2009. http://thoughtleader.co.za/bryanmukandi/2009/01/07/the-house-of-hunger/. Accessed 30 Jan. 2018.

Nicholls, Brendon. "Postcolonial Narcissism, Cryptopolitics, and Hypnocritique: Dambudzo Marechera's The House of Hunger". Postcolonial Text vol. 8, no. 2, 2013, pp. 1-22.

Power, Chris. "A brief survey of the short story, part 54: Dambudzo Marechera". The Guardian, 2014. https:// www.theguardian.com/books/booksblog/2014/jan/07/survey-short-story-dambudzo-marechera. Accessed 18 Feb. 2018.

Rudge, Trudy and Dave Holmes, eds. Abjectly Boundless: Boundaries, Bodies and Health Work. Ashgate, 2010. 
Said, Edward W. Orientalism. Random House, 1979.

Taitz, Laurice. "Knocking on the Door of the House of Hunger: Fracturing Narratives and Disordering Identity". Emerging Perspectives on Dambudzo Marechera. Eds. Flora Veit-Wild and Anthony Chennells. Africa World Press, 1999, pp. 23-42.

Veit-Wild, Flora and Anthony Chennells, eds. Emerging Perspectives on Dambudzo Marechera. Africa World Press, 1999.

. "Introduction: The Man Who Betrayed Africa? Emerging Perspectives on Dambudzo Marechera. Eds. Flora Veit-Wild and Anthony Chennells. African World Press, 1999, pp. xi-xix.

Ward, Alan Ramón. "The Embrace of Exclusion: The Collective and the Corporeal in Dambudzo Marechera's 'House of Hunger'”. English Studies in Africa vol. 56, no. 2, 2013, pp. 73-83. DOI: https://doi. org/10.1080/00138398.2013.856561. 